\title{
Timing of diuretics in diuresis renography
}

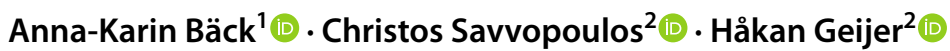

Received: 30 April 2021 / Accepted: 5 August 2021 / Published online: 19 August 2021

(c) The Author(s) 2021

\begin{abstract}
Purpose The aim of this systematic literature review was to obtain an overview of when to administer the diuretics in relation to the radiopharmaceutical during a diuresis renography.

Methods A systematic literature search was performed in three different databases (Embase, PubMed/Medline and Cochrane Library) together with an information specialist. The review question was: when should diuretics be administered in relation to the radiopharmaceutical in a diuresis renography? Studies of adults were included together with guidelines published in collaboration with an organization.

Results Seventeen articles and four guidelines were retrieved in the literature search. The F - 15 method (diuretics administered $15 \mathrm{~min}$ before the radiopharmaceutical) was the one that was studied and described most and was compared with other time points for diuretic administration. The retrieved articles and guidelines report of advantages with different time points for diuretics. Both $\mathrm{F}-15$ and $\mathrm{F}+0$ are reported to clarify washout in equivocal cases compared to $\mathrm{F}+20$.

Conclusion No consensus could be found for a preferred time point of diuretics administration during a diuresis renography.
\end{abstract}

Keywords Renography $\cdot$ Diuresis renography $\cdot$ Diuretic timing $\cdot$ Furosemide

\section{Introduction}

A diuresis renography is an examination where a diuretic, commonly furosemide, is administered during radionuclide renography to distinguish between obstruction and prolonged renal drainage [1,2]. Furosemide increases the urine flow rate and has a rapid onset. Its renal action begins within the first few minutes after intravenous diuretic administration and the maximal urinary flow rate occurs after approximately $15 \mathrm{~min}$ [3]. However, in an obstructed kidney, the washout can remain slow even after diuretic administration with a prolonged retention of radiopharmaceutical proximal to the obstruction [4].

There is variability in the methodology of renographies between different Nuclear Medicine departments, mostly concerning the timing of the diuretic administration in relation to the radiopharmaceutical administration.

Anna-Karin Bäck

anna-karin.back@oru.se

1 Division of Medical Diagnostics, School of Health Sciences, Örebro University, Örebro, Sweden

2 Department of Radiology, Faculty of Medicine and Health, Örebro University, Örebro, Sweden
A study or a method where the diuretic is administered after the radiopharmaceutical is described as $\mathrm{F}+$ and before the radiopharmaceuticals as $\mathrm{F}-$. The $\mathrm{F}+20$ method, i.e. diuretics given $20 \mathrm{~min}$ after the radiopharmaceutical, has been considered to be the traditional method [2].

There have been reports of modified methods of the traditional diuresis renography where other time points for diuretic administration were described. One such method was the F - 15 where the diuretics were administered 15 min before the radiopharmaceutical and another method was $\mathrm{F}+0$ with the diuretics administered at the same time as the radiopharmaceutical, summarized by O'Reilly [2]. Other time points of diuretics are used as well in diuresis renographies.

\section{Aim}

The aim of this literature review was to obtain an overview of when to administer the diuretics in relation to the radiopharmaceutical during a diuresis renography. Is there a preferred time point of diuretics administration during a diuresis renography? 


\section{Materials and methods}

This systematic literature review was registered in the Prospero database (CRD42020167484) and followed the method "Preferred Reporting Items for Systematic Reviews and Meta-Analyses" (PRISMA) [5]. The PICO method, where four different areas are described (Population, Intervention, Comparison, Outcome) [6] was used to address the review question. The PICO aimed to give an overview of when to administer diuretics in relation to the radiopharmaceutical in diuresis renography, Table 1.

\section{Literature search}

The primary literature search was performed in May 2019 in three different databases for published articles and guidelines (Embase, PubMed/Medline and Cochrane Library) together with an information specialist. A secondary search was performed in February 2021 to include newer publications.

Synonyms of the words renography and diuretics were combined and used as search expressions to address the PICO question, Appendix 1. There was no limitation as to the publication year in the literature search process.

Duplicates were removed before two researchers (AKB and HG) individually read the retrieved titles and abstracts from the literature search. Abstracts that were selected by at least one reader were read independently in full text by both readers.

The collected articles and guidelines had to have been published in a paper listed in the Web of Science and written in English to be selected for full-text reading. Guidelines of relevant topics published in collaboration with an organization were also included. The content of the articles and guidelines had to concern diuresis renographies of adults where the timing of furosemide in relation to a radiopharmaceutical were studied or described. Non-original articles, articles on topics not relevant to the study, or articles that only included children were excluded, Appendix 2. Disagreements after full-text reading were resolved by consensus between the two readers. Basic information, such as author, country, year of publication, study type and number of participants were noted for each included article.
The radiopharmaceuticals that were used in the performed renographies and the different timepoints of the administered diuretics were noted as well.

\section{Data extraction}

Data extraction was performed and double-checked by two researchers (AKB and CS). Due to the lack of homogenous numerical results, a meta-analysis could not be performed, and the results are reported in a narrative format.

\section{Quality assessment}

A quality assessment form influenced by QUADAS-2 and the Newcastle-Ottawa scale was created and used when assessing the included articles [7, 8]. The quality assessment form contained nine questions in four different domains as well as a domain question which summarized each domain, Table 2.

Each article was graded individually by two researchers (AKB and $\mathrm{HG}$ ) using a three-grade scale when assessing the different domain questions (low risk or high risk for bias, and unclear). Guidelines were not included in the quality assessment process. No exclusions were made during this process.

\section{Results}

There were 17 articles and four guidelines relevant to the review question, Fig. 1.

The included articles were published between the years 1978 and 2020 [9-25]. The number of participants varied between 14 and 320 . The radiopharmaceutical ${ }^{99 \mathrm{~m}} \mathrm{Tc}-\mathrm{MAG} 3$ was administered in six studies $[11,17-19,24,25],{ }^{99 \mathrm{~m}} \mathrm{Tc}-$ DTPA in five studies $[9,12,13,20,22],{ }^{123} \mathrm{I}$-OIH in four studies $[15,16,21,23],{ }^{99 \mathrm{~m}} \mathrm{Tc}-\mathrm{EC}$ in one study [10] and one study did not mention which radiopharmaceutical had been administered [14]. Five studies had a retrospective study design $[15,17,22,24,25]$ and 12 studies had a prospective study design [9-14, 16, 18-21, 23]. Four articles included both children and adults in their studies [16, 17, 20, 22], Table 3.
Table 1 The review question and the four different areas: population, intervention, comparison and outcome

\begin{tabular}{ll}
\hline $\begin{array}{l}\text { PICO } \\
\text { Review question }\end{array}$ & $\begin{array}{l}\text { When should diuretics be administered in relation to the radiopharmaceuti- } \\
\text { cal in a renography, } \mathrm{F}+10, \mathrm{~F}+20 \text { or other? } \\
\text { Population } \\
\text { Intervention }\end{array}$ \\
$\begin{array}{l}\text { Adult patients with the clinical question of obstruction or split renal function } \\
\text { The time of furosemide administration in relation to the radiopharmaceutical } \\
\text { administration during a renography } \\
\text { Other timepoints for diuretic administration or no administration }\end{array}$ \\
Outcome
\end{tabular}




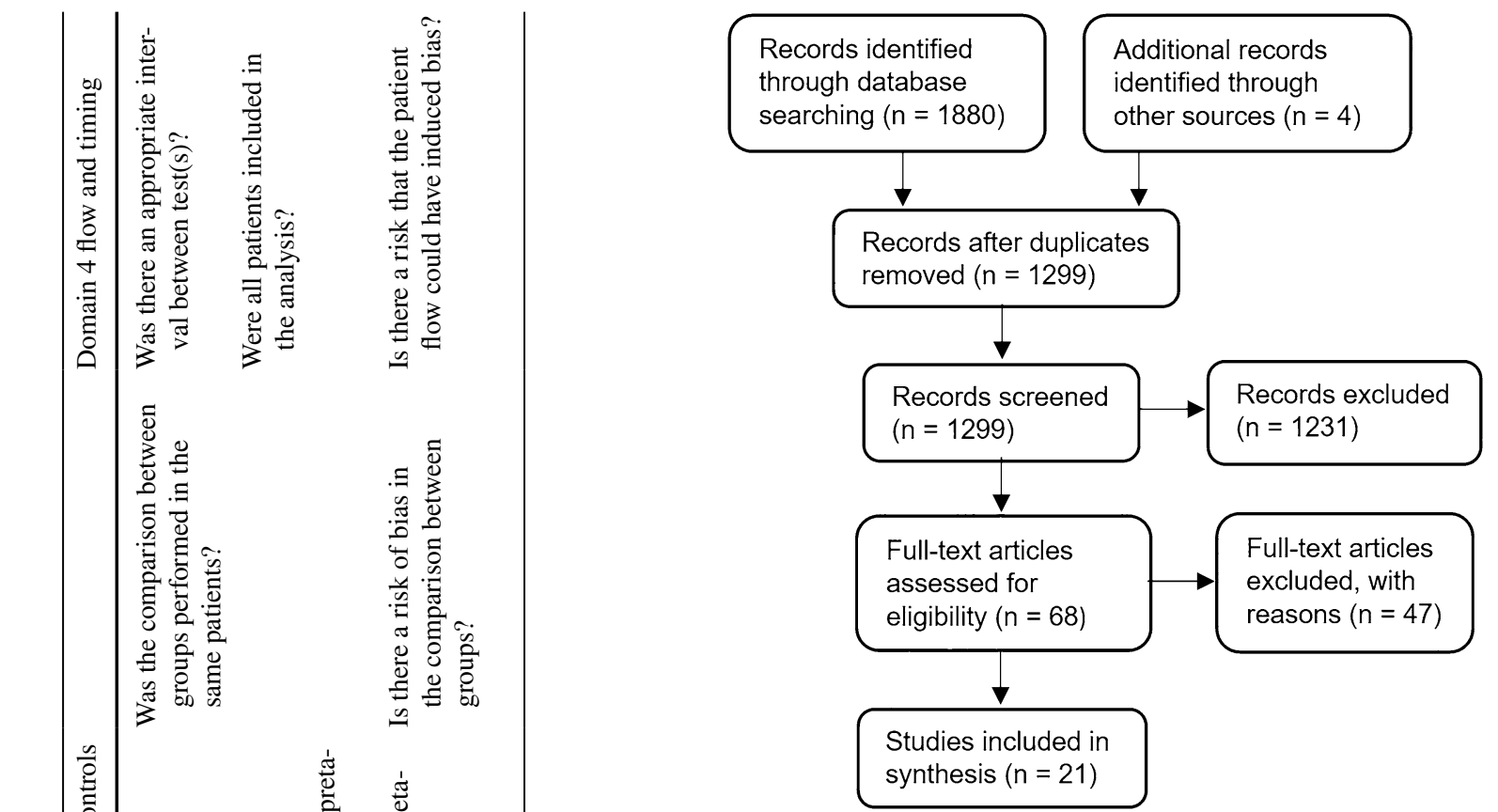

Fig. 1 Study flow diagram

The F - 15 method was the method that was studied and described most in the published articles. Five studies compared the F - 15 method with the standard, F+20 method $[9,10,14-16]$. The $\mathrm{F}-15$ method gave fewer equivocal results and led to clarification in cases of equivocal results compared to the F+20 method [9, 10, 15]. Furthermore, an equivocal response in $\mathrm{F}+20$ could be converted to a normal response by $\mathrm{F}-15$ [14]. English et al. reported that the F-15 method could increase the specificity of diuresis renography in patients with equivocal pelviureteric junction obstruction [16].

Sultan et al. compared the F - 15 method with the F+15 method and concluded that the F -15 method resulted in fewer equivocal results than the F+15 method did [13]. Turkölmez et al. compared three different methods ( $\mathrm{F}-15$, $\mathrm{F}+0$ and $\mathrm{F}+20$ ) with each other in the same patient group. The reported results were that the $\mathrm{F}+0$ and the $\mathrm{F}-15$ methods allowed classification of equivocal $\mathrm{F}+20$ results. Furthermore, that the $\mathrm{F}+0$ method is a more practical and shorter technique than $\mathrm{F}-15$ and therefore a better alternative, especially if there is only one opportunity to confirm or exclude obstruction [18]. Adeyoju et al. included three different methods as well and compared the $\mathrm{F}+0$ method with the F -15 method or the F+20 method in their study. They reported that the $\mathrm{F}-15$ method had the best record in terms of reducing equivocal results compared to both $\mathrm{F}+20$ and $\mathrm{F}+0$. Moreover, that the $\mathrm{F}+0$ method gave similar results to $\mathrm{F}+20$ but could reduce the time required compared to $\mathrm{F}+20$ [11]. Liu et al. compared the $\mathrm{F}+0$ method 
Table 3 Articles and guidelines in PICO

\begin{tabular}{|c|c|c|c|c|c|c|c|c|c|}
\hline \multirow{2}{*}{$\begin{array}{l}\text { Author } \\
\text { [reference] } \\
\text { Country or } \\
\text { Organisation }\end{array}$} & \multirow[t]{2}{*}{ Year } & \multirow{2}{*}{$\begin{array}{l}\text { Type of } \\
\text { study } \\
\text { Participants }\end{array}$} & \multirow[t]{2}{*}{ Study aim } & \multirow{2}{*}{$\begin{array}{c}\text { Radiopharmaceutical } \\
\text { (described diuretic } \\
\text { timepoint(s)) }\end{array}$} & \multirow[t]{2}{*}{ Outcome } & \multicolumn{4}{|c|}{ Quality Assessment } \\
\hline & & & & & & $\begin{array}{l}\text { Domain } \\
1\end{array}$ & $\begin{array}{l}\text { Domain } \\
2\end{array}$ & $\underset{3}{\text { Domain }}$ & $\begin{array}{l}\text { Domain } \\
4\end{array}$ \\
\hline $\begin{array}{l}\text { Sachpekidis } \\
{[25]} \\
\text { Switzerland }\end{array}$ & 2020 & $\begin{array}{l}\text { Retrospective } \\
120 \text { patients }\end{array}$ & $\begin{array}{l}\text { To evaluate the intra- and inter-observer } \\
\text { agreement when assessing the renal } \\
\text { function in } 99 \text { 9mmC-MAG3 diuretic } \\
\text { renographies }\end{array}$ & ${ }^{99 \mathrm{~m} T \mathrm{C}-M A G 3}(\mathrm{~F}+10)$ & $\begin{array}{l}\text { The reader's experience is important when } \\
\text { calculating renal parameters as the } \\
\text { assessment of differential renal function and } \\
\text { Tmax. Reader training could be of value. The } \\
\text { manual tool was better in assigning regions of } \\
\text { interests than the semi-automated tool }\end{array}$ & 0 & O & & 0 \\
\hline $\begin{array}{l}\text { Bäck [24] } \\
\text { Sweden }\end{array}$ & 2020 & $\begin{array}{l}\text { Retrospective } \\
320 \text { patients }\end{array}$ & $\begin{array}{l}\text { To discover a cutoff value of residual } \\
\text { radioactivity in the kidneys at } 7 \text { minutes } \\
\text { into the } F+10 \text { renography, to use as a } \\
\text { threshold in the diuretic decision }\end{array}$ & ${ }^{99 m T} \mathrm{C}-M A G 3(F+10)$ & $\begin{array}{c}F+10 \text { renography is feasible and acceptable in } \\
\text { clinical practice. The suggested cutoff value to } \\
\text { use in clinical practice is } 85 \% \text { of the maximum } \\
\text { activity }\end{array}$ & 0 & 0 & & 0 \\
\hline$\underset{\text { India }}{\text { Kumar }}$ & 2018 & $\begin{array}{l}\text { Prospective } \\
51 \text { patients }\end{array}$ & $\begin{array}{l}\text { To investigate if } F-15 \text { can reduce } \\
\text { inconclusive results of } F+20 \text { in } \\
\text { hydronephrotic kidneys }\end{array}$ & $\begin{array}{l}\text { 99mTC-DTPA (F-15 and } \\
F+20)\end{array}$ & $\begin{array}{l}F-15 \text { showed significantly less equivocal } \\
\text { results and clarification in cases of equivocal } \\
\text { results of } F+20 \text { protocol }\end{array}$ & 0 & O & 0 & 0 \\
\hline$\underset{\text { Egypt }}{\text { Kandeel }[20]}$ & 2013 & $\begin{array}{l}\text { Prospective } \\
102 \text { patients } \\
\text { (including } \\
\text { children) }\end{array}$ & $\begin{array}{l}\text { The effect of timing, } \mathrm{F}+0 \text { or } \mathrm{F}+10 \text {, on the } \\
\text { split renal function compared with }{ }^{99 m \mathrm{TC}} \text { - } \\
\text { DMSA }\end{array}$ & $\begin{array}{l}{ }^{99 m} \mathrm{~m} C-D T P A(F+0 \text { and } \\
F+10)\end{array}$ & $\begin{array}{l}\text { Discrepancy in split renal function between } \\
\qquad F+0 \text { and } F+10 \text { in favour of } F+10\end{array}$ & 0 & O & - & 0 \\
\hline $\begin{array}{l}\text { Tartaglione } \\
{[19] \text { Italy }}\end{array}$ & 2013 & $\begin{array}{l}\text { Prospective } \\
36 \text { patients }\end{array}$ & $\begin{array}{l}\text { To compare } F+10 \text { with } F-15 \text { for diagnosis } \\
\text { of obstructive uropathy }\end{array}$ & $\begin{array}{l}\text { 99mTc-MAG3 }(F+10 \\
\quad \text { and F-15) }\end{array}$ & $\begin{array}{l}\mathrm{F}+10 \text { (seated position) reduces the equivocal } \\
\text { findings of F-15. The lower dose and a better } \\
\text { timing of diuretics could lead to less bladder } \\
\text { filling related problems and therefore improve } \\
\text { patients' compliance }\end{array}$ & O & 0 & 0 & 0 \\
\hline $\begin{array}{l}\text { Taghavi [10] } \\
\text { Iran }\end{array}$ & 2007 & $\begin{array}{l}\text { Prospective } \\
21 \text { patients }\end{array}$ & $\begin{array}{l}\text { To compare } F-15 \text { with } F+20 \text { in patients } \\
\text { with upper urinary tract dilatation }\end{array}$ & $\begin{array}{c}{ }^{99 m} \mathrm{Tc}-\mathrm{EC}(\mathrm{F}+20 \text { and } \\
\mathrm{F}-15)\end{array}$ & $\begin{array}{l}\text { Obstruction was discovered in more cases by } \\
\text { the } F-15 \text { method than by the } F+20 \text { method. } F- \\
15 \text { protocol may reduce the equivocal results } \\
\text { of the } F+20 \text {. }\end{array}$ & O & O & 0 & 0 \\
\hline Liu [17] USA & 2005 & $\begin{array}{l}\text { Retrospective } \\
85 \text { patients } \\
\text { (including } \\
\text { children) }\end{array}$ & $\begin{array}{l}\text { To compare if } \mathrm{F}+0 \text { resulted in more } \\
\text { patients able to complete the acquisition } \\
\text { without disruption due to voiding than } \mathrm{F} \text { - } \\
15\end{array}$ & $\begin{array}{l}{ }^{99 m} \text { TC-MAG3 }(F+0 \text { and } \\
\text { F-15) }\end{array}$ & $\begin{array}{l}\text { More renographies were interrupted because } \\
\text { of voiding in the } F-15 \text { cohort than in the } F+0 \\
\text { cohort }\end{array}$ & 0 & 0 & ○ & - \\
\hline $\begin{array}{l}\text { Turkolmez } \\
\text { [18] Turkey }\end{array}$ & 2004 & $\begin{array}{l}\text { Prospective } \\
22 \text { patients }\end{array}$ & $\begin{array}{l}\text { To compare the diagnostic impact of } \\
F+20, F-15 \text {, and } F+0 \text { in cases with upper } \\
\text { urinary tract dilatatation }\end{array}$ & $\begin{array}{l}{ }^{99 m} \text { TC-MAG3 }(F+20, F- \\
15 \text { and F+0) }\end{array}$ & $\begin{array}{l}F+0 \text { and } F-15 \text { allowed classification in cases of } \\
\text { equivocal } F+20 \text { studies. } F+0 \text { is recommended } \\
\text { when equivocal results are obtained by } F+20 \\
\text { or when only one opportunity exists to confirm } \\
\text { or exclude obstruction }\end{array}$ & O & 0 & 0 & - \\
\hline$\underset{\mathrm{UK}}{\text { Adeyoju [11] }}$ & 2001 & $\begin{array}{l}\text { Prospective } \\
29 \text { patients }\end{array}$ & $\begin{array}{l}\text { To investigate } F+0 \text { with } F+20 \text { or } F-15 \text { in } \\
\text { the effect on assessing split renal function } \\
\text { and interpreting upper tract drainage } \\
\text { dynamics }\end{array}$ & $\begin{array}{l}\text { 99mTc-MAG3 }(F+0 \\
F+20 \text { and } F-15)\end{array}$ & $\begin{array}{l}\text { F+0 gives similar results to the conventional } \\
\text { techniques, reduces the time required, but } \\
\text { may not be useful in evaluating the grossly } \\
\text { dilated upper tract. F-15 has the best record in } \\
\text { terms of reducing equivocal results }\end{array}$ & O & 0 & 0 & 0 \\
\hline $\begin{array}{l}\text { Altarac [12] } \\
\text { UK }\end{array}$ & 1998 & $\begin{array}{l}\text { Prospective } \\
28 \text { patients }\end{array}$ & $\begin{array}{l}\text { To introduce and evaluate an obstruction } \\
\text { score, based on the } F-15 \text { renographic } \\
\text { washout curve analysis }\end{array}$ & ${ }^{99 \mathrm{~m} T \mathrm{C}-D T P A}(\mathrm{~F}-15)$ & $\begin{array}{l}\text { The obstruction score system is a } \\
\text { sophisticated interpretation approach to the } \\
\text { renographic washout curve }\end{array}$ & 0 & 0 & & 0 \\
\hline $\begin{array}{l}\text { Sultan [13] } \\
\text { Pakistan }\end{array}$ & 1996 & $\begin{array}{l}\text { Prospective } \\
52 \text { patients }\end{array}$ & $\begin{array}{c}\text { To compare the role of } F+15 \text { and } F-15 \text { in } \\
\text { the evaluation of ureteropelvic junction } \\
\text { obstruction }\end{array}$ & $\begin{array}{l}\text { 99mTC-DTPA (F+15 } \\
\text { and F-15) }\end{array}$ & $\begin{array}{l}F+15 \text { gave a reliable assessment of the upper } \\
\text { tract drainage. Equivocal cases were resolved } \\
\text { by the } F-15 \text { and were more conclusive in } \\
\text { assessment compared to } F+15\end{array}$ & O & 0 & 0 & - \\
\hline $\begin{array}{l}\text { Upsdell [15] } \\
\text { UK }\end{array}$ & 1992 & $\begin{array}{l}\text { Retrospective } \\
50 \text { patients }\end{array}$ & $\begin{array}{l}\text { To report the results of a long-term follow- } \\
\text { up study of patients investigated by the F- } \\
15 \text { method compared with } \mathrm{F}+20\end{array}$ & $\begin{array}{c}123 \mathrm{I}-\mathrm{OlH}(\mathrm{F}-15 \text { and } \\
\mathrm{F}+20)\end{array}$ & $\begin{array}{l}\text { F-15 agreed in unobstructed cases, confirmed } \\
\text { unobstruction in some hypotonic washout } \\
\text { cases and clarified washout in most equivocal } \\
\text { washout cases compared to standard method }\end{array}$ & 0 & 0 & 0 & 0 \\
\hline $\begin{array}{l}\text { Upsdell [14] } \\
\text { UK }\end{array}$ & 1988 & $\begin{array}{l}\text { Prospective } \\
14 \text { patients }\end{array}$ & $\begin{array}{l}\text { To report the relation between urinary flow } \\
\text { rates induced by diuretics and creatinine } \\
\text { clearance levels. Also, the differences in } \\
\text { split renal function and washout curves } \\
\text { between } F+20 \text { and } F-15 \text { in a separate } \\
\text { study }\end{array}$ & $\begin{array}{l}\text { Not mentioned (F+20 } \\
\text { and F-15) }\end{array}$ & $\begin{array}{l}\text { There was no statistical difference in the split } \\
\text { renal function between } F+20 \text { and } F-15 \text {. An } \\
\text { equivocal response in } F+20 \text { was converted to } \\
\text { a normal response by } F-15 \text { in } 4 \text { of } 14 \text { washout } \\
\text { curves }\end{array}$ & - & - & 0 & ○ \\
\hline$\underset{U K}{\text { English [16] }}$ & 1987 & $\begin{array}{l}\text { Prospective } \\
30 \text { patients } \\
\text { (including } \\
\text { children) }\end{array}$ & $\begin{array}{l}\text { To report a modification of the standard } \\
\text { diuresis renography }\end{array}$ & $\begin{array}{c}123-\mathrm{OIH}(\mathrm{F}-15 \text { and } \\
\mathrm{F}+20)\end{array}$ & $\begin{array}{l}\text { F-15 increases the specificity of diuresis } \\
\text { renography in patients with equivocal } \\
\text { pelviureteric junction obstruction }\end{array}$ & - & 0 & 0 & - \\
\hline $\begin{array}{c}\text { Arap [21] } \\
\text { Brazil }\end{array}$ & 1984 & $\begin{array}{l}\text { Prospective } \\
32 \text { patients }\end{array}$ & $\begin{array}{l}\text { To differentiate between obstructed and } \\
\text { atonic ureters with diuretic stimulus }\end{array}$ & ${ }^{123}$-OIH $(F+15)$ & $\begin{array}{l}\text { Diuretic stimulus allows differentiation between } \\
\text { obstructive and hypotonic processes by } \\
\text { stimulating the washout of the } \\
\text { radiopharmaceutical from the nonobstructed } \\
\text { urinary tract }\end{array}$ & O & 0 & & 0 \\
\hline Koff [22] USA & 1979 & $\begin{array}{l}\text { Retrospective } \\
41 \text { patients } \\
\text { (including } \\
\text { children) }\end{array}$ & $\begin{array}{l}\text { To present the methodology and results of } \\
\text { diuretic radionuclide urography }\end{array}$ & ${ }^{99 m T C-D T P A}(F+10-20)$ & $\begin{array}{l}\text { The three different and clinically significant } \\
\text { patterns of radionuclide uptake and excretion } \\
\text { were described: Normal, dilated non- } \\
\text { obstructed and obstructed }\end{array}$ & - & - & & 0 \\
\hline $\begin{array}{l}\text { O'Reilly [23] } \\
\text { UK }\end{array}$ & 1978 & $\begin{array}{l}\text { Prospective } \\
52 \text { patients }\end{array}$ & $\begin{array}{l}\text { To describe a non-invasive method of } \\
\text { investigating equivocal upper tract } \\
\text { obstruction with diuretic provocation }\end{array}$ & ${ }^{123} \mathrm{I}-\mathrm{OIH}(\mathrm{F}+30)$ & $\begin{array}{l}\text { The function and drainage capability can be } \\
\text { assessed with this method and is } \\
\text { recommended in all states of equivocal } \\
\text { obstruction before proceeding to more } \\
\text { invasive procedures }\end{array}$ & O & 0 & 0 & 0 \\
\hline $\begin{array}{l}\text { Taylor [26] } \\
\text { SNMMI and } \\
\text { EANM }\end{array}$ & 2018 & Guideline & $\begin{array}{l}\text { Recommending, performing, interpreting } \\
\text { and reporting diuretic renal scintigraphy in } \\
\text { the setting of suspected renal obstruction } \\
\text { in adults }\end{array}$ & 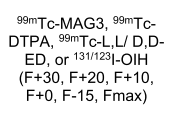 & $\begin{array}{l}\mathrm{F}+0 \text { is most convenient and minimizes } \\
\text { imaging time, } \mathrm{F}-15 \text { and } \mathrm{F}+10 \mathrm{sp} \text { allow better } \\
\text { discrimination between obstructed and } \\
\text { nonobstructed kidneys. } \mathrm{F}+20, \mathrm{~F}+30, \mathrm{Fmax} \\
\text { dual-acquisition protocols allow observation of } \\
\text { natural urinary drainage kinetics }\end{array}$ & & & & \\
\hline $\begin{array}{c}\text { British } \\
\text { Nuclear } \\
\text { Medicine } \\
\text { Society [27] }\end{array}$ & $2011 / 2018$ & Guideline & $\begin{array}{l}\text { Recommending, performing, interpreting } \\
\text { and reporting the results of dynamic renal } \\
\text { radionuclide studies }\end{array}$ & $\begin{array}{c}{ }^{99 m \mathrm{~m} C-D T P A},{ }^{99 m T C-} \\
\text { MAG3 or }{ }^{99 m T C ~ M D P ~} \\
\text { (medronate) (F+20, } \\
\text { F+0, F-15) }\end{array}$ & $\begin{array}{l}F+20 \text { can be used when the kidneys have not } \\
\text { emptied satisfactorily during the first } 20 \\
\text { minutes of acquisition, } F-15 \text { when knowledge } \\
\text { or suspicion of obstruction exists beforehand, } \\
F+0 \text { is commonly used in paediatrics }\end{array}$ & & & & \\
\hline $\begin{array}{l}\text { François [28] } \\
\text { EANM } \\
\text { (Technologist } \\
\text { guide) }\end{array}$ & 2009 & $\begin{array}{l}\text { Technologist } \\
\text { guide }\end{array}$ & $\begin{array}{l}\text { A technologist guide that focuses on } \\
\text { dynamic imaging techniques in } \\
\text { obstructive renal pathology }\end{array}$ & $\begin{array}{l}{ }^{99 m} \mathrm{MC}-\mathrm{DTPA} \text { or }{ }^{99 m \mathrm{mT}-} \\
\text { MAG3 }(\mathrm{F}-15, \mathrm{~F}+0 \\
\mathrm{F}+10, \mathrm{~F}+15, \mathrm{~F}+20)\end{array}$ & $\begin{array}{l}\text { There is no consensus as to the time of } \\
\text { furosemide administration in renographies }\end{array}$ & & & & \\
\hline $\begin{array}{l}\text { O'Reilly [29] } \\
\text { International } \\
\text { Consensus } \\
\text { Committee }\end{array}$ & 1996 & $\begin{array}{l}\text { Consensus } \\
\text { report }\end{array}$ & $\begin{array}{l}\text { To standardize the technical aspects, } \\
\text { performance and interpretation of diuresis } \\
\text { renography }\end{array}$ & $\begin{array}{l}\text { 99mTc-MAG3, }{ }^{999 m T C-} \\
\text { DTPA, }{ }^{123} \text { II-OIH }(F+20 \\
\quad F+0, F-15)\end{array}$ & $\begin{array}{l}\mathrm{F}-15 \text { is recommended when the } \mathrm{F}+20 \text { is } \\
\text { equivocal, or as a one-stop maximal-diuresis } \\
\text { renogram instead of the traditional } \mathrm{F}+20 \\
\text { technique }\end{array}$ & & & & \\
\hline
\end{tabular}

The table also visualizes the quality assessment in four different domains graded in three different colors: $\bigcirc=$ low risk/low concern, $\bullet=$ high risk/high concern, = unclear 
with $\mathrm{F}-15$ method and reported that a greater part of the patients could complete the diuresis renography with the $\mathrm{F}+0$ method since more examinations were reported to be disrupted with the F - 15 method due to voiding issues [17].

Three articles reported results concerning administering the diuretics $10 \mathrm{~min}$ after the radiopharmaceutical i.e., the F+10 method [19, 20, 24]. Tartaglione et al. reported that the F+10 method (in seated position) could reduce the equivocal findings of the F - 15 method (in supine position) and lead to fewer bladder filling related problems. However, a lower dose of diuretics was administered in the $\mathrm{F}+10$ method compared to the $\mathrm{F}-15$ method in this study [19]. Kandeel et al. compared F+ 0 with $\mathrm{F}+10$ and reported a discrepancy in split renal function between $\mathrm{F}+0$ and $\mathrm{F}+10$ and in favor of $F+10$ [20]. Bäck et al. compared a modified $\mathrm{F}+10$ method (with a cut-off value for diuretic decision) with the F+20 method and reported the F+10 method to be a feasible and acceptable method in clinical practice [24].

Five studies did not compare different methods with each other; instead, they addressed a certain question and described which of the different methods they had used in their studies [12, 21-23, 25]. Arap et al. described the F+15 method and reported that diuretic administration allowed differentiation between obstructive and hypotonic processes [21]. Koff et al. presented a methodology and results of diuresis renography where the diuretics were administered 10-20 min after the radiopharmaceutical [22]. O'Reilly et al. described the F+30 method and reported the method to be a method of investigating equivocal urinary upper tract obstruction with diuretic provocation [23]. Altarac S. introduced and evaluated an obstruction score system based on the F - 15 method [12]. Sachpekidis et al. evaluated the intra- and inter-observer agreement when assessing the renal function in diuresis renography when using the $\mathrm{F}+10$ method and, reported that the reader's experience is important when calculating renal parameters and that reader training could be of value [25].

Four guidelines published between 1996 and 2018 were found in the literature search process [26-29], Table 3. The different methods concerning time points for diuretic administration that are described in all four guidelines are $\mathrm{F}-15$, $\mathrm{F}+0$, and $\mathrm{F}+20$ [26-29]. The F+10 method is described in two guidelines [26, 28]. The F +30 method and the Fmax (diuretic administration when the activity in the collecting system appears to have reached a maximum) are described in one guideline [26] and the F+15 method is described in one guideline [28].

The British Nuclear Medicine Society state in their guideline that when an obstruction is known beforehand, the $\mathrm{F}-15$ or the $\mathrm{F}+0$ methods could be used and that the $\mathrm{F}+0$ method often is used in pediatrics [27]. The International Consensus Committee reported in their guideline that the F - 15 method is recommended when the $\mathrm{F}+20$ is equivocal, or as a one-stop maximal-diuresis renogram instead of the traditional F+20 method [29]. Another guideline by European Association of Nuclear Medicine in collaboration with Society of Nuclear Medicine and Molecular Imaging states that the $\mathrm{F}-15$ method could allow better discrimination between obstructed and nonobstructed kidneys. Furthermore, that the F+10 method (in seated position) has been reported to give comparable or superior results to the F - 15 method and, that the F +0 method could minimize imaging time and, therefore, be the most convenient method [26].

As a summary, all the described different renography methods can be used when the function and drainage capability are to be assessed. The F+20 method can be used when the kidneys have not emptied satisfactorily during the first 20 min of acquisition [22, 26, 27]. The F -15 method has been reported to agree with $\mathrm{F}+20$ in unobstructed cases and show less equivocal results and clarification in cases of equivocal results with $\mathrm{F}+20[9-11,14-16,26,29]$. The $\mathrm{F}+0$ method can be used when only one opportunity exists to confirm or exclude obstruction [18]. Furthermore, it can minimize the examination time and make less examinations interrupted because of voiding issues than the $\mathrm{F}-15$ method $[17,26]$. The $F+10$ method in seated position could reduce the equivocal findings of the $\mathrm{F}-15$ method. This method has a shorter examination time than the F -15 and gives information about baseline state [19].

None of the guidelines recommended one single method concerning an optimal time point as to when the diuretics should be administered in relation to the radiopharmaceutical.

\section{Quality assessment}

The quality assessment revealed that some studies could introduce bias in more than one domain. However, no exclusion was made during this process. The quality assessment revealed a low risk of bias when assessing the conduct of the index test or its interpretation (domain 2) as well as when the comparison between groups was assessed (domain 3). The highest risk of bias was found in the domain where the flow and timing were assessed (domain 4). The domain where the patient selection was assessed (domain 1) had the most unclear issues, Table 3.

\section{Discussion}

A systematic literature review has been performed in three different databases to achieve a broad search. The authors chose to not set a limit in the publication year of the articles in the literature search, which resulted in articles published as early as 1978 and as late as 2020 . However, not 
many published studies could be found in the literature search process. Some studies were included in this study despite the fact that they did not compare different diuresis renography methods with each other. Instead, they studied a certain issue and described a method with a specific time point for diuretic administration in relation to the radiopharmaceutical, these studies are reported separately in the result section.

No exclusions were made during the quality assessment process as we wanted to report results from all included articles found in our literature search. Domain 1 had more unclear issues than the other domains as several of the included studies did not clearly describe how the selection of the study subjects had been performed. Furthermore, a higher score was achieved in domain 3 if the comparison between groups involved the same patients. A higher score was also given when the comparison between groups was performed close to each other (within 2 weeks).

A limitation of this study is that no meta-analysis could be performed. Furthermore, there were few published studies comparing different time points for diuretic administration in a diuresis renography which could be a future area of research. In addition, articles containing only children as study subjects were excluded in the literature search process but articles involving both adults and children were included.

\section{Conclusion}

Both $\mathrm{F}-15$ and $\mathrm{F}+0$ are reported to clarify washout in equivocal cases compared to $\mathrm{F}+20$ but no consensus could be found for a preferred time point of diuretics administration during a diuresis renography.

Supplementary Information The online version contains supplementary material available at https://doi.org/10.1007/s40336-021-00461-w.

Acknowledgements We thank librarian Liz Holmgren for help with the literature search.

Author contributions All authors contributed to the study conception and design. $\mathrm{A}-\mathrm{KB}$ and $\mathrm{HG}$ performed the literature search and the quality assessment. A-KB and CS performed the data analysis. A-KB drafted the work and CS and HG critically revised the work.

Funding Open access funding provided by Örebro University. This work was supported by Region Örebro County through the regional research board (Grant OLL-915121, 11 June 2019).

\section{Declarations}

Conflict of interest The authors (Anna-Karin Bäck, Christos Savvopoulos and Håkan Geijer) report no conflict of interest.
Declaration of Helsinki The study was performed in accordance with the Declaration of Helsinki. This study was registered with PROSPERO (CRD42020167484, 7 February 2020).

Ethical approval No individual patient data were evaluated during the study and the included primary studies had undergone separate ethics approvals.

Consent for publication All authors (Anna-Karin Bäck, Christos Savvopoulos and Håkan Geijer) read and approved the final manuscript.

Open Access This article is licensed under a Creative Commons Attribution 4.0 International License, which permits use, sharing, adaptation, distribution and reproduction in any medium or format, as long as you give appropriate credit to the original author(s) and the source, provide a link to the Creative Commons licence, and indicate if changes were made. The images or other third party material in this article are included in the article's Creative Commons licence, unless indicated otherwise in a credit line to the material. If material is not included in the article's Creative Commons licence and your intended use is not permitted by statutory regulation or exceeds the permitted use, you will need to obtain permission directly from the copyright holder. To view a copy of this licence, visit http://creativecommons.org/licenses/by/4.0/.

\section{References}

1. O'Reilly PH (1992) Diuresis renography. Recent advances and recommended protocols. Br J Urol 69:113-120

2. O'Reilly PH (2003) Standardization of the renogram technique for investigating the dilated upper urinary tract and assessing the results of surgery. BJU Int 91:239-243

3. Brown SC, Upsdell SM, O'Reilly PH (1992) The importance of renal function in the interpretation of diuresis renography. $\mathrm{Br} \mathrm{J}$ Urol 69:121-125

4. Thrall JH, Koff SA, Keyes JW Jr (1981) Diuretic radionuclide renography and scintigraphy in the differential diagnosis of hydroureteronephrosis. Semin Nucl Med 11:89-104

5. Moher D, Liberati A, Tetzlaff J, Altman DG, The Prisma Group (2009) Preferred reporting items for systematic reviews and meta-analyses: the PRISMA statement. PLoS Med 6:e1000097. https://doi.org/10.1371/journal.pmed.1000097

6. McKenzie JE, Brennan SE, Ryan RE, Thomson HJ, Johnston RV, Thomas J (2021) Defining the criteria for including studies and how they will be grouped for the synthesis. In: Higgins JPT, Thomas J, Chandler J, Cumpston M, Li T, Page MJ, Welch VA (eds) Cochrane Handbook for Systematic Reviews of Interventions version 6.2 (updated February 2021). Chap 3, Cochrane. Available from www.training.cochrane.org/handbook

7. Whiting PF, Rutjes AW, Westwood ME, Mallett S, Deeks JJ, Reitsma JB, QUADAS-2 Group et al (2011) QUADAS-2: a revised tool for the quality assessment of diagnostic accuracy studies. Ann Intern Med. https://doi.org/10.7326/0003-4819155-8-201110180-00009 ((PMID: 22007046))

8. Wells GA, Shea B, O'Connell D, Peterson J, Welch V, Losos M, Tugwell P (2020) The Newcastle-Ottawa Scale (NOS) for assessing the quality of nonrandomised studies in meta-analyses. The Ottawa Hospital Research Institute. http://www.ohri. ca/programs/clinical_epidemiology/oxford.asp. Accessed Dec 2020

9. Kumar MT, Hanuwant S (2018) Comparison of the F + 20 and $\mathrm{F}-15$ diuresis technetium-99m diethylenetriaminepentacetate renography protocols for diagnosis of ureteropelvic junction 
obstruction in adult patients with hydronephrosis. Indian J Nucl Med 33:39-42. https://doi.org/10.4103/ijnm.IJNM_113_17

10. Taghavi R, Ariana K, Arab D (2007) Diuresis renography for differentiation of upper urinary tract dilatation from obstruction: $\mathrm{F}+20$ and $\mathrm{F}-15$ methods. Urol J 4:36-40

11. Adeyoju AA, Burke D, Atkinson C, McKie C, Pollard AJ, O'Reilly PH (2001) The choice of timing for diuresis renography: the $\mathrm{F}+0$ method. BJU Int $88: 1-5$

12. Altarac S (1998) Obstruction score of ureteropelvic junction investigated by modified $\mathrm{F}-15$ diuresis renography. Croat Med J 39:33-40

13. Sultan S, Zaman M, Kamal S, Zafar N, Naqvi A, Rizvi A (1996) Evaluation of ureteropelvic junction obstruction (UPJO) by diuretic renography. J Pak Med Assoc 46:143-147

14. Upsdell SM, Leeson SM, Brooman PJ, O'Reilly PH (1988) Diuretic-induced urinary flow rates at varying clearances and their relevance to the performance and interpretation of diuresis renography. Br J Urol 61:14-18

15. Upsdell SM, Testa HJ, Lawson RS (1992) The F - 15 diuresis renogram in suspected obstruction of the upper urinary tract. $\mathrm{Br}$ J Urol 69:126-131

16. English PJ, Testa HJ, Lawson RS, Carroll RN, Edwards EC (1987) Modified method of diuresis renography for the assessment of equivocal pelviureteric junction obstruction. Br J Urol 59:10-14

17. Liu Y, Ghesani NV, Skurnick JH, Zuckier LS (2005) The F + 0 protocol for diuretic renography results in fewer interrupted studies due to voiding than the F -15 protocol. J Nucl Med 46:1317-1320

18. Turkolmez S, Atasever T, Turkolmez K, Gogus O (2004) Comparison of three different diuretic renal scintigraphy protocols in patients with dilated upper urinary tracts. Clin Nucl Med 29:154-160

19. Tartaglione G, D’Addessi A, De Waure C, Pagan M, Raccioppi M, Sacco E et al (2013) (99m)Tc-MAG3 diuretic renography in diagnosis of obstructive nephropathy in adults: a comparison between $\mathrm{F}-15$ and a new procedure $\mathrm{F}+10(\mathrm{sp})$ in seated position. Clin Nucl Med 38:432-436. https://doi.org/10.1097/RLU.0b013e3182 $8 \mathrm{da} 3 \mathrm{f5}$

20. Kandeel AA, Elhossainy SA, Elsayed ND (2013) Influence of early $(F+0)$ intravenous furosemide injection on the split renal function using 99mTc-DTPA renography. Nucl Med Commun 34:354-358. https://doi.org/10.1097/MNM.0b013e32835e7437

21. Arap S, Nahas WC, Alonso G, Denes FT, Martins LR, Menezes de Goes G (1984) Assessment of hydroureteronephrosis by renographic evaluation under diuretic stimulus. Urol Int 39:170-174. https://doi.org/10.1159/000280968
22. Koff SA, Thrall JH, Keyes JW (1979) Diuretic radionuclide urography: a non-invasive method for evaluating nephroureteral dilatation. J Urol 122:451-454

23. O'Reilly PH, Testa HJ, Lawson RS, Farrar DJ, Edwards EC (1978) Diuresis renography in equivocal urinary tract obstruction. Br J Urol 50:76-80

24. Bäck AK, Savvopoulos C, Kero T, Grybäck P, Geijer H (2020) Renography with a semiautomated algorithm for diuretic decision 7 min postradiopharmaceutical administration: a feasibility study. Nucl Med Commun 41:1018-1025. https://doi.org/10.1097/mnm. 0000000000001261

25. Sachpekidis C, Schepers R, Marti M, Kopp-Schneider A, Alberts I, Keramida G et al (2020) (99m)Tc-MAG3 diuretic renography: intra- and inter-observer repeatability in the assessment of renal function. Diagnostics (Basel). https://doi.org/10.3390/diagnostic s10090709

26. Taylor AT, Brandon DC, de Palma D, Blaufox MD, Durand E, Erbas B et al (2018) SNMMI procedure standard/EANM practice guideline for diuretic renal scintigraphy in adults with suspected upper urinary tract obstruction 1.0. Semin Nucl Med 48:377-390. https://doi.org/10.1053/j.semnuclmed.2018.02.010

27. British Nuclear Medicine Society (BNMS) (2011) Dynamic renal radionuclide studies (renography) clinical guidelines British Nuclear Medicine Society (BNMS) (reviewed October 2018). https://www.bnms.org.uk/page/BNMSClinicalGuidelin es. Accessed Dec 2020

28. François H, Dennan S, Boubaker A, Lapeirre G, Richardson A, Van den Heuvel et al (2009) Dynamic ****renal imaging in obstructive renal pathology. A technologist's guide EANM website: European Association of Nuclear Medicine. http://www. eanm.org/publications/technologists-guide/dynamic-renal-imagi ng/. Accessed Dec 2020

29. O'Reilly P, Aurell M, Britton K, Kletter K, Rosenthal L, Testa $\mathrm{T}$ (1996) Consensus on diuresis renography for investigating the dilated upper urinary tract. Radionuclides in Nephrourology Group. Consensus Committee on Diuresis Renography. J Nucl Med 37:1872-1876

Publisher's Note Springer Nature remains neutral with regard to jurisdictional claims in published maps and institutional affiliations. 